\title{
Web Watch: tracking tobacco on the Internet
}

A few months ago, my nine-year-old son Evan, who is a Cub Scout, began work on his pinewood derby car for this year's contest. This is an activity in which Scouts, usually with assistance from a parent, carve a race car from a block of pinewood, and race them down a long track. Awards are given for the fastest cars and the most unique designs.

After a rather mediocre performance in the Pinewood Derbies of the past few years, Evan and I decided to go all out for the 1997 event. However, not being an automotive engineer, as are many Cub Scout fathers in Michigan, and having failed to inherit my own father's carpentry genes, I was in a weak position to improve Evan's prospects for a Derby medal. But then we figured we'd check out the Net. And sure enough, we found a number of Web sites that gave detailed instructions on how to make a speedy vehicle, along with pictures of beautifully creative Derby cars. Armed with those ideas and guidelines, we were soon making what turned out to be a winning entry.

Just about everyone, these days, has a story like that to tell about a valuable find on the Internet. The information explosion on the Web has been particularly awesome in the area of health and medicine. Books and newsletters devoted exclusively to medicine on the Internet are now available. ${ }^{1-3}$ Some medical publications feature regular columns on the subject, in a desperate attempt to keep up with the fast-paced changes on the Web. For example, the $B M \mathcal{F}$ has a column called "Netlines", which provides short descriptions of a pot-pourri of medically related Web sites. $\mathcal{F} A M A$ runs articles under the banner "NetSight: A Guide to Interactive Medicine", which describe how to access health information on the Net. ${ }^{46}$ American Medical News publishes "NETworking - a monthly collection of hot spots, tips and tidbits for Interneting physicians".

Information on tobacco has spread through the Web at breakneck speed. On 28 March, I plugged the keyword "tobacco" into various search engines, and turned up the following numbers of matches: 86891 , Excite; 69406 , Infoseek; 16 034, Lycos; 3872, WebCrawler; and 252, Yahoo. Data on tobacco use, tobacco-related diseases, legislation, and other areas of interest are available on the Internet, making it a valuable tool for research on tobacco.

Through Tobacco Control we have attempted to keep readers informed of pertinent developments on the Web. We published a comprehensive article on tobacco-related resources on the Internet in our Winter 1995 issue, $^{7}$ and news articles in the journal have also reported on recent developments. ${ }^{89}$ But there is so much to report on, and it is all changing so rapidly, that periodic articles are not enough. So we have decided to launch a regular column on the subject in Tobacco Control-called Web Watch.

Web Watch will report on the most important happenings on the Internet with respect to tobacco. The inaugural column, appearing in this issue of the journal (see page 147), describes a wide range of Web sites, including those related to the California Environmental Protection Agency's report on passive smoking, class-action lawsuits against the tobacco industry, pesticide residues in tobacco products, and industry front groups. Web sites operated by tobacco companies themselves are also reviewed, including a youth-oriented site for the Camel Party Zone, operated out of South Africa.

Jack Cannon is our Web Watch correspondent. He brings to this role a wealth of computer skills and a singular devotion to tobacco control. Jack has 21 years of experience in state-of-the-art computer technology research and development. He holds a number of patents, has authored more than 40 publications in the fields of computer science and hardware development, and operates his own tobacco Web site <http://www.gate.net/ -jcannon/tobacco.html>.

We hope this column will help readers navigate through the far reaches of cyberspace. We encourage readers to share with us their observations and opinions about what is happening on the Internet.

Editor

RONALD M DAVIS

1 Hogarth M, Hutchinson. An Internet guide for the health professional. Sacramento, California: New Wind Publishing, 1996. (1995 edition available online at <http://www.newwindpub.com>)

Linden T, Kienholz ML. Dr. Tom Linden's guide to online medicine. New York McGraw-Hill, 1995

3 Medicine on the Net (ISSN 1085-3502). P Engstrom, ed. Monthly newsletter published by COR Healthcare Resources, Santa Barbara, California (mednet@corhealth.com).

4 Peters R, Sikorski R. The Web, unplugged: Hardware, software, and connections. $\mathscr{F} A M A$ 1996;276:1607-8.

5 Sikorski R, Peters R. Internet Anatomy 101: Accessing information on the World Wide Web. $\mathcal{F} A M A$ 1997;277:171-2.

6 Peters R, Sikorski R. Tools for finding information on the Internet. $7 A M A$ 1997;277:505-6.

7 Hayman $M$. Tobacco related resources on the Internet. Tobacco Control 1995;4:387-90.

8 Simpson D. Through the Net. Tobacco Control 1996;5:11.

9 Simpson D. GLOBALink. Tobacco Control 1997;6:86. 